\title{
Influence of Dust Deposition on the Electrical Parameters of Silicon-Based Solar Panels Installed in Senegal (Dakar Region)
}

\author{
Dialo Diop ${ }^{*}$, Moulaye Diagne ${ }^{2}$, Abel Sambou ${ }^{1}$, Pascal Djicoly Bassene ${ }^{1}$, \\ Serigne Abdoul Aziz Niang1, Astou Sarr ${ }^{1}$
}

${ }^{1}$ Groupe des Laboratoires de Physique des Solides des Sciences des Matériaux (GLPSSM), Département de Physique, Faculté des Sciences et Techniques (FST), Université Cheikh Anta Diop, Dakar, Sénégal

${ }^{2}$ Laboratory of Semiconductor and Solar Energy, Department of Physics, Faculty of Science and Techniques, University Cheikh Anta Diop, Dakar, Senegal

Email: ^dialo.diop.ucad@gmail.com

How to cite this paper: Diop, D., Diagne, M., Sambou, A., Bassene, P.D., Niang, S.A.A. and Sarr, A. (2021) Influence of Dust Deposition on the Electrical Parameters of Silicon-Based Solar Panels Installed in Senegal (Dakar Region). Energy and Power Engineering, 13, 174-189.

https://doi.org/10.4236/epe.2021.135012

Received: April 20, 2021

Accepted: May 28, 2021

Published: May 31, 2021

Copyright $\odot 2021$ by author(s) and Scientific Research Publishing Inc. This work is licensed under the Creative Commons Attribution International License (CC BY 4.0).

http://creativecommons.org/licenses/by/4.0/

\begin{abstract}
In recent years, photovoltaic (PV) modules are widely used in many applications around the world. However, this renewable energy is plagued by dust, airborne particles, humidity, and high ambient temperatures. This paper studies the effect of dust soiling on silicon-based photovoltaic panel performance in a mini-solar power plant located in Dakar (Senegal, $14^{\circ} 42^{\prime} \mathrm{N}$ latitude, $17^{\circ} 28^{\prime} \mathrm{W}$ longitude). Results of the current-voltage (I - V) characteristics of photovoltaic panels tested under real conditions. We modeled a silicon-based $\mathrm{PV}$ cell in a dusty environment as a stack of thin layers of dust, glass and silicon. The silicon layer is modeled as a P-N junction. The study performed under standard laboratory conditions with input data of irradiation at 1000 $\mathrm{W} / \mathrm{m}^{2}$, cell temperature at $25^{\circ} \mathrm{C}$ and solar spectrum with Air Mass (AM) at 1.5 for the monocrystalline silicon PV cell ( $\mathrm{m}-\mathrm{Si}$ ). The analysis with an ellipsometer of dust samples collected on photovoltaic panels allowed to obtain the refraction indices (real and imaginary) of these particles which will complete the input parameters of the model. Results show that for a photon flux arriving on dust layer of $70 \mu \mathrm{m}$ (corresponding to dust deposit of $3.3 \mathrm{~g} / \mathrm{m}^{2}$ ) deposited on silicon-based PV cells, short circuit current decreases from 54 $\mathrm{mA}$ (for a clean cell) to $26 \mathrm{~mA}$. Also, conversion efficiency decreases by $50 \%$ compared to clean cell and the cell fill factor decreases by $76 \%-50 \%$ compared to reference PV cell.
\end{abstract}

\section{Keywords}

Dust Deposition, PV Cell, Fill Factor, Modeling, Ellipsometer 


\section{Introduction}

The rapid growth of photovoltaic technologies in the world is very important and contributed to global electricity generation [1] [2]. Research and development in the field of solar energy continue to focus primarily on optimizing the efficiency of PV cells. With 3.000 hours of sunshine per year and global irradiation of $5.8 \mathrm{kWh} / \mathrm{m}^{2} /$ day, Senegal has a significant potential for the development of photovoltaic power generation [3] [4] [5]. Solar production is affected by several factors such as local environment, weather conditions, PV panel tilt angle, dust accumulated on PV cells, etc. [1] [2]. Among these different factors, deposition of dust on PV cell surfaces is a crucial element that affects their performances. In fact, after their manufacture, solar panels are installed and exposed in open air for electricity generation. Thus, the accumulation of dust on their surface gives rise to the thin layer. Thus, the layer with some thickness can mask exposure to sun and absorb some incident radiation beam. This led to a significant decrease in the electrical parameters [6] [7]. In addition, solar production is also affected by several factors such as local environment, weather conditions, PV panel tilt angle, dust accumulated on PV cells, etc. [8] [9] [10] [11]. Among these different factors, deposition of dust on PV cell surfaces is a crucial element to study. It is a natural phenomenon and depends on several parameters such as local environment and meteorological parameters [12] [13]. Senegal is close to Sahara Desert and this region is among the largest sources of dust in the world [14]. According to Paudyal and Shakya [15], decrease in electricity production due to dust deposits was $3.16 \%$ in one day, reached $10.41 \%$ in ten days and finally $15.74 \%$ in one month. Thus, Kaldellis and Kapsali [16] and Moehlecke [17] showed that solar energy production decreases significantly in presence of dust. For example, Chanchangi et al. [18] used a solar simulator and studied the effect of accumulation of 13 different samples (ashes, bird droppings, carpet dust, cement, dust, etc.) on the performance of PV modules. Afterwards, they noted a decrease of about $98 \%$ in short circuit current. Similarly, Adıüzel et al. [19] found $15 \mathrm{~g}$ of dust on crystalline silicon modules, power loss of $62 \%$. Moreover, Hachicha et al. (2019) [20] collected dust of different sizes (from 1.61 to 38.40 $\mu \mathrm{m})$ and various shapes. They concluded that the yield decreases by $1.7 \%$ per $\mathrm{g} / \mathrm{m}^{2}$ of accumulated dust. In addition, Jiang and Sun [21] presented monocrystalline silicon (mc-Si), polycrystalline silicon ( $\mathrm{pc}-\mathrm{Si}$ ) and amorphous silicon (a-Si) technologies. Their results showed $0 \%-26 \%$ yield reduction for dust deposits increasing from 0 to $22 \mathrm{~g} / \mathrm{m}^{2}$. In Senegal, Ndiaye et al. [6] exposed PV panels to natural climatic factors for one year and found maximum power decrease of $18 \%-78 \%$ for polycrystalline and monocrystalline modules, respectively. Said and Walwil [22] noted an average reduction in short circuit current of about $13 \%$ after 5 weeks of exposure. In fact, several studies on factors affecting photovoltaic energy have been carried out worldwide [23], in Africa and particularly in Senegal. However, modeling studies focusing on interaction of solar radiation with dust deposited on surfaces of these PV cells are still missing. Therefore, a 
comparative approach of two PV cells has been adopted in this work to study the influence of dust deposits on operating characteristics of PV cells. In addition, research and development in the field of solar energy continue to focus primarily on optimizing the efficiency of PV cells. This paper aims to contribute the improvement of performance of PV cells in Senegal. We study losses of short circuit current, power output, conversion efficiency and fill factor of PV cells as a function of dust deposit on their surfaces.

The paper is divided into three parts. The first part presents methodology (modeling). Then, the second part presents the results of simulations resulting from modeling of the losses of electrical parameters of silicon-based solar cell in presence of dust deposit on the surface. Finally, the last part presents the conclusion.

\section{Methods}

The monocrystalline silicon cell installed in a dusty environment is modeled as a stack of thin layers (dust/glass/silicon) as shown in Figure 1. This allows to evaluate the electrical losses of solar cells in presence of dust on the surface of PV modules. Reflection and transmission coefficients at the interface of these layers obtained from refractive indices of the dust. Thus, the dust refraction is obtained thanks to an ellipsometer that analyzes collected dust samples. Also, the global reflectance of multilayer system obtained from the Fresnel reflection and transmission coefficients. Thus, the refraction indices and global reflectances of the different layers will be used as input data for the model. The influence of dust on the energy production of silicon-based solar cell has studied. Silicon layer is considered as an N-P junction structure as shown in Figure 2. This model used to determine the current densities, various cell characteristics such as short-circuit current, open circuit voltage, power output, conversion efficiency and form factor of the PV cell in the presence of dust deposition on the PV surface in all N, P and space charge area (SCA) zones of the solar cell. When surface of cell is illuminated by flow of light, the cell creates charge carriers such as electrons and holes. Electron-hole pairs created in the space charge zone of P-N junction are immediately separated by a electric field in this region and carried

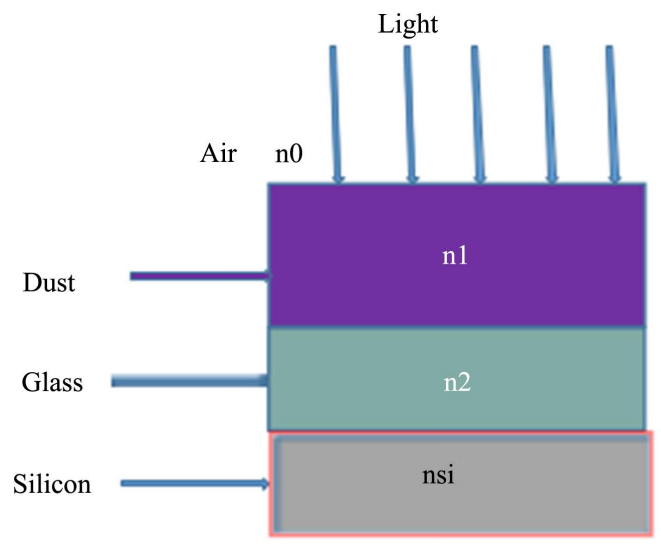

Figure 1. Stacting of dust/glass/silicon. 


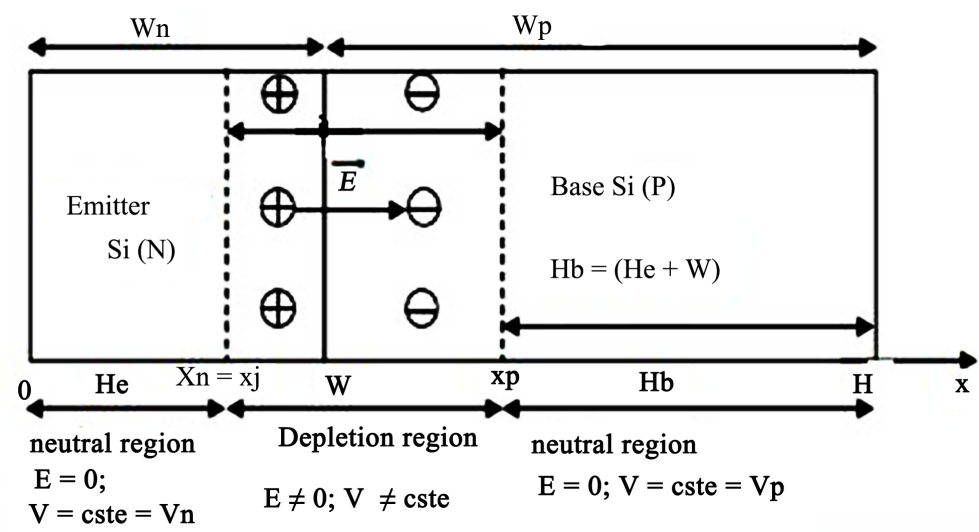

Figure 2. Dimensions of $\mathrm{Si}(\mathrm{N}) / \mathrm{Si}(\mathrm{P})$ silicon-based solar cell.

into. They carried the neutral zones on either side of the junction. If the device is insulated, a potential difference appears across the junction and if it is connected to an external electric charge, free electrons must pass through the charge to recombine with positive holes; thus, current can be generated from the cells under illumination [24].

Thus, to study the influence of dust on energy production of silicon-based solar cell, the silicon layer considered as an N-P junction structure as shown in Figure 2. It allows to study the influence of dust on energy production of silicon-based solar cell.

In our study, the surface transport of minority carriers and consequently the surface current is neglected. The continuity equation allows to determine, at any point and at any time, the concentration of carriers in a semiconductor. When light illuminates the surface of the emitter with certain wavelength $\lambda$, there is an electron-hole pair generation whose generation rate $G(\lambda)$ is expressed by Equation (1) [24] [25]. This model developed by Mahfoud [26].

$$
G(\lambda)=\alpha(\lambda) \cdot F(\lambda) \cdot[1-R(\lambda)] \cdot \exp (-\alpha x)
$$

$F(\lambda)$ : Spectral flux of incident photons,

$\alpha(\lambda)$ : Absorption coefficient of the material,

$R(\lambda)$ : Reflection coefficient at surface of the material.

However, the pairs photogenerated carriers do not remain static and their continuity equation is written [27]:

$$
D \cdot \frac{\partial^{2} \delta(x)}{\partial x^{2}}+G(\lambda)-\frac{\delta(x)}{\tau}=0
$$

$D$ : Diffusion coefficient of minority carriers,

$\delta(x)$ : Excess minority carrier's density,

$\tau$. lifetime of electrons.

\subsection{Density of Excess Minority Holders in the Base}

Minority charge carriers generated (electrons) in P-type base of the photopile, under effect of illumination with monochromatic light, are electrons of charge 
-q. Indeed, density of these generated carriers in the base is determined from continuity equation. Thus, when we consider phenomena of generation, recombination and diffusion of excess minority carriers in the base, this equation is written in a static regime [27]:

$$
D_{n} \cdot \frac{\mathrm{d}^{2}\left(n_{p}-n_{p 0}\right)}{\mathrm{d} x^{2}}+G(\lambda)-\frac{n_{p}-n_{p 0}}{\tau_{n}}=0
$$

$n_{p}-n_{p 0}=\delta(x)$ : density of the electrons generated in the base;

$n_{p 0}$ : density of electrons generated at equilibrium;

$D_{n}$ : minority carriers' diffusion of electrons in base and n: electrons in base.

Indeed, this continuity equation admits for general solution as:

$$
n_{p}-n_{p 0}=A \cosh \left(\frac{x}{L_{n}}\right)+B \sinh \left(\frac{x}{L_{n}}\right)-\alpha \times F \times(1-R) \frac{\tau_{n}}{\alpha^{2} \times L_{n}^{2}-1} \exp (-\alpha x)
$$

where $L_{n}$ is the minority carriers diffusion length in the base and the coefficients $A$ and $C$ are determinated by the following boundary conditions:

$$
n_{p}-n_{p 0}=0
$$

Thus, density of minority carriers is as follows [28]:

Boundary conditions:

- With $x=H_{e}+w$ and $x=H$, we have:

$$
\begin{gathered}
S_{n} \times\left(n_{p}-n_{p 0}\right)=\frac{-D_{n} \times \mathrm{d}\left(n_{p}-n_{p 0}\right)}{\mathrm{d} x} \\
n_{p}-n_{p 0}=\frac{\alpha \times F(1-R) \times \tau_{n}}{\alpha^{2} \times L_{n}^{2}-1} \times \mathrm{e}^{-\alpha\left(H_{e}+w\right)} \times\left[\cosh \frac{x-H_{e}-w}{L_{n}}-\mathrm{e}^{-\alpha\left(x-H_{e}-w\right)}\right. \\
-\frac{\frac{S_{n} L_{n}}{D_{n}}\left(\cosh \frac{H_{b}}{L_{n}}-\exp \left(-\alpha H_{b}\right)\right)+\sinh \frac{H_{b}}{L_{n}}+\alpha L_{n} \exp \left(-\alpha H_{b}\right)}{\frac{S_{n} L_{n}}{D_{n}} \times \sinh \frac{H_{b}}{L_{n}}+\cosh \frac{H_{b}}{L_{n}}} \\
\left.\times \sinh \frac{x-H_{e}-w}{L_{n}}\right]
\end{gathered}
$$

$\tau_{n}:$ lifetime expectancy in the base,

$w$. width of the PN and $S_{n}$ junction: recombination speed on the back surface, $H_{e}$ et $H_{b}$ : width of the transmitter $(P)$ and the base with $H_{b}=H-\left(H_{e}+W\right)$, $D_{n}$ : distribution ratio of excess minority shareholders.

In the issuer, the charge carriers obey the following continuity equation:

$$
D_{p} \cdot \frac{\mathrm{d}^{2}\left(p_{n}-p_{n 0}\right)}{\mathrm{d} x^{2}}+G(\lambda)-\frac{p_{n}-p_{n 0}}{\tau_{p}}=0
$$

$P_{n}-P_{n 0}$ : density of excess minority carriers and $P_{n 0}$ : density or concentration of excess minority carriers at thermodynamic equilibrium;

$\tau_{p}$ : lifetime of excess minority shareholders.

- Boundary conditions below, the equations below can be solved:

- At the junction $(x=0)$; the rear side $\left(x=H_{e}\right)$ and $P_{n}-P_{n 0}=0$ 


$$
\begin{gathered}
\frac{D_{p} \times \mathrm{d}\left(P_{n}-P_{n 0}\right)}{\mathrm{d} x}=S_{p}\left(P_{n}-P_{n 0}\right) \\
p_{n}-p_{n o}=\frac{\alpha \times F(1-R) \times \tau_{p}}{\alpha^{2} \times L_{p}^{2}-1} \\
\times\left[\frac{\left(\frac{S_{p} L_{p}}{D_{p}}+\alpha \times L_{p}\right) \sinh \frac{H_{e}-x}{L_{n}}+\left(\frac{S_{p} L_{p}}{D_{p}} \sinh \frac{x}{L_{p}}+\cosh \frac{x}{L_{p}}\right) \exp \left(-\alpha H_{e}\right)}{\frac{S_{p} L_{p}}{D_{p}} \times \sinh \frac{H_{e}}{L_{p}}+\cosh \frac{H_{e}}{L_{p}}}-\mathrm{e}^{-\alpha x}\right]
\end{gathered}
$$

$S_{p}$ : front surface recombination velocities and $D_{p}$ : hole diffusion coefficient ; $L_{p}$ : hole diffusion length.

\subsection{Calculation of the Density of the Photocurrent in the Base}

In PN junction cell, photocurrent generated by charge carriers (electrons) is written [29].

$$
I_{\mathrm{ph}}=q \cdot A \times\left(\frac{\partial\left(n_{p}-n_{p 0}\right)}{\partial x}\right)_{x=H_{e}+w}
$$

$q$ is the electron elementary charge.

$A$ : illuminated surface of cell and the corresponding photocurrent density is:

$$
\begin{gathered}
J_{\mathrm{ph}}=\frac{I_{\mathrm{ph}}}{A}=q \times D_{n} \times\left(\frac{\partial\left(n_{p}-n_{p 0}\right)}{\partial x}\right)_{x=H_{e}+w} \\
J_{n}=\frac{q \cdot F(1-R) \cdot \alpha L_{n}}{\alpha^{2} \cdot L_{n}^{2}-1} \times \mathrm{e}^{-\alpha\left(H_{e}+w\right)}
\end{gathered}
$$

\subsection{Calculation of Density of the Photo-Current in the Emitter}

When we use the Equation (14), we found the photocurrent density in the emitter by using the Equation (15):

$$
J_{\mathrm{ph}}=\frac{I_{\mathrm{ph}}}{A}=q \times D_{p} \times\left(\frac{\partial\left(n_{p}-n_{p 0}\right)}{\partial x}\right)_{x=0}
$$

$J_{p}=\frac{q \times F(1-R) \times \alpha L_{p}}{\alpha^{2} \times L_{n}^{2}-1}$

$$
\times\left[\frac{\left(\frac{S_{p} L_{p}}{D_{p}}+\alpha \times L_{p}\right)-\frac{S_{p} L_{p}}{D_{p}} \cosh \frac{x}{L_{n}}+\left(\frac{S_{p} L_{p}}{D_{p}} \cosh \frac{x}{L_{p}}+\sinh \frac{x}{L_{p}}\right) \exp \left(-\alpha H_{e}\right)}{\frac{S_{p} L_{p}}{D_{p}} \times \sinh \frac{x_{j}}{L_{p}}+\cosh \frac{H_{e}}{L_{p}}}-\alpha L_{p} \mathrm{e}^{-\alpha x}\right]
$$

\subsection{Calculation of the Density of the Photo-Current in the Space Charge Zone (ZCE)}

In this zone, photocurrent density is given by [27]: 


$$
J_{\text {zce }}=q \times F(1-R) \times \exp \left(-\alpha H_{e}\right) \times\left(1-\mathrm{e}^{-\alpha w}\right)
$$

\subsection{Total Photocurent Density}

Total photocurrent density is sum of photocurrent densities of three zones (P-N-ZCE) of photopile and is written as follow [30]:

$$
J_{\mathrm{ph}}=J_{n}+J_{P}+J_{\text {zce }}
$$

The photocurrent density over the entire spectrum is obtained by integrating $J_{\mathrm{ph}}$ current density over entire range of the solar spectrum used. Thus, $J_{\text {tot }}$ is given by:

$$
J_{\text {tot }}=\int_{\lambda_{\min }}^{\lambda_{\max }} J_{\mathrm{ph}} \cdot \mathrm{d} \lambda
$$

All expressions used to calculate open circuit voltage $\left(V_{c o}\right)$, maximum power $\left(P_{m}\right)$, conversion efficiency $(\eta)$ obtained from [31].

$$
P_{m}=V_{\text {max }} \times I_{\text {max }}
$$

The Fill Factor (FF) and conversion efficiency $(\eta)$ are expressed below as [32] [33].

$$
\mathrm{FF}=\frac{P_{m}}{V_{\mathrm{co}} \times I_{\mathrm{cc}}} ; \eta=\frac{P_{m}}{P_{i}}=\frac{\mathrm{FF} \times I_{\mathrm{cc}} \times V_{\mathrm{co}}}{P_{i}}
$$

$V_{c o}, I_{c o} P_{i}$ respectively, open circuit voltage, short circuit current and incident light power. $V_{m}, I_{m}$ and $P_{m}$ are respectively, voltage, current and maximum power.

\section{Results and Discussions}

In addition to standard parameters, we need the real and imaginary refractive indices of dust to feed our model. For this purpose, we collected samples of dust deposited on surface of the solar module in Dakar. These samples analyzed by ellipsometry to obtain optical indices of particles deposited in Dakar over a period of one year. Thus, Figure 3 shows the variation of real (Figure 3(a)) and imaginary (Figure 3(b)) indices of dust deposited on the PV cell surfaces as a function of wavelength. They will be used as input parameters for the model. Indeed, imaginary refractive indices of the dust collected on the PV cell surfaces over the whole spectrum obtained by the ellipsometer are a bit high compared to the results of Colarco et al. [34]. They found mean imaginary aerosol indices above Dakar at shorter wavelengths. This difference in value is explained by the shift in the collection date and the composition of the dust which varies according to the weather and weather conditions. However, the refraction indices found in this study according to the work [35] [36] [37] [38] show the presence of pure minerals and clays in this composition. These confirm that indices provided by the ellipsometer correspond to dust indices of the locality. Moreover, according to work of Veselovskii et al. [39], the values of real dust indices of Dakar, Senegal could be between 1.35 to 1.65 and those of the imaginary indices between 0 to 0.02 and these values are quite close to those of the ellipsometer. 


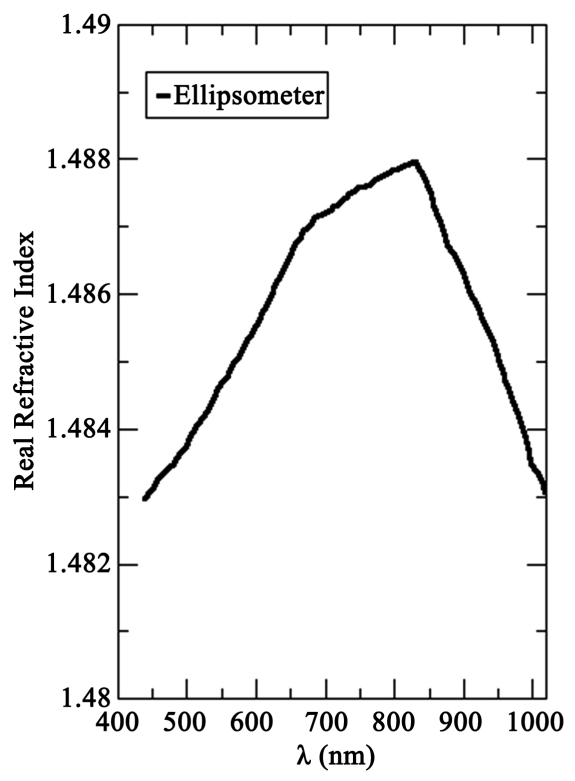

(a)

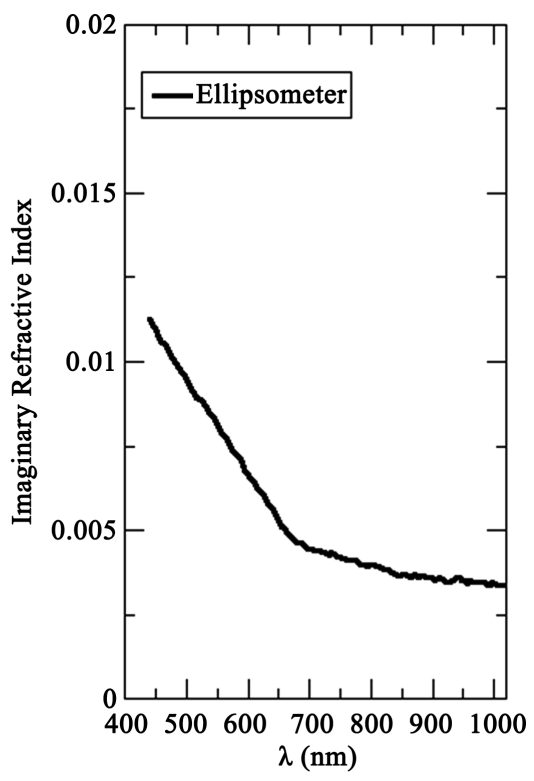

(b)

Figure 3. Refractive indices of Saharan dust. Real index of dust particles (a) Imaginary in dex of dust particles (b).

Figure 4 shows the evolution of photocurrent density (J) of the PV cell for different dust layer thicknesses varying from $30,45,55$ and $70 \mu \mathrm{m}$ corresponding respectively to dust deposit of $1.4 ; 2.1 ; 2.6$ and $3.3 \mathrm{~g} / \mathrm{m}^{2}$. It represents $\mathrm{J}-\mathrm{V}$ characteristic for different dust deposits on surface of PV cell. Short-circuit current of the cell decreases sharply as size of the dust layer increases. For a clean cell (black curve on Figure 4) without dust, short circuit current is $54.44 \mathrm{~mA}$. However, as dust accumulate on the surface of these panels, there is gradual decrease in this short circuit current. For layer of 30, 45, 55 and $70 \mu \mathrm{m}$, short circuit current is $33.5,32.44,30.54$ and $26.45 \mathrm{~mA}$ respectively. Indeed, when dust settles on the surface of cell, a large part of the light reflected and the photon flux arriving at the surface reduced. This leads to a decrease in the temperature inside the cell. According to Mahfoud [26], this decrease in short-circuit current is due to decrease in photon flux reaching the cell surface. Consequently, a dust layer $70 \mu \mathrm{m}$ thick leads to $51 \%$ reduction of this current compared to that of the clean cell.

These results were consistent with Chanchangi et al. [18]. They showed that short circuit current of PV cells reduced by $46 \%$ when bird droppings deposited on PV surfaces. In addition, these figures show that deposition of dust on PV cells slightly reduces open circuit voltage as shown by Mani and Pillai [9]. Other results such as [40] [41] corroborate with our results. Their work showed that dust reduces short circuit current of solar cells. Moreover, according to Klugmann-Radziemska [42], short circuit current depends on irradiation. So, irradiation reaching the cell decreases with the increase of dust deposited on PV cell surface.

Figure 5 shows evolution of power produced by the silicon cell for different layers of dust deposited on cell surface as a function of the supply voltage. Clean 


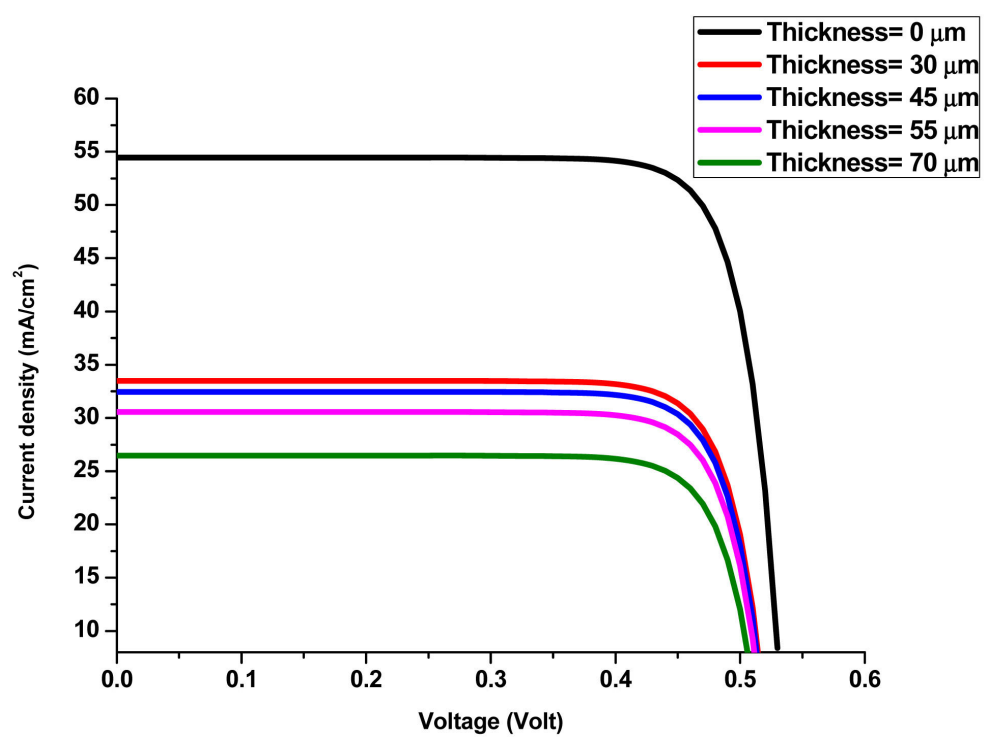

Figure 4. Current-voltage characteristics of cell for different dust layer thicknesses.

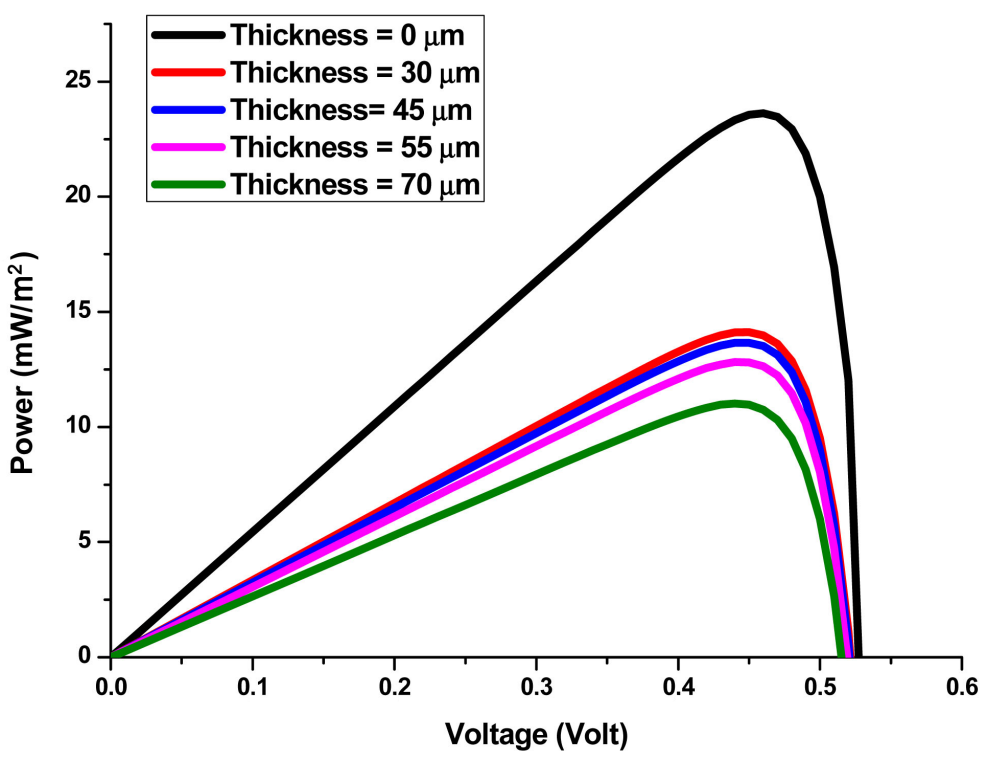

Figure 5. Power-voltage characteristic of cell for different dust layer thicknesses.

cell (dust layer thickness $0 \mu \mathrm{m}$ corresponds to dust-free cell) whose power output represented by the black curve and the green curve corresponds power output of the room cell when a dust layer of $70 \mu \mathrm{m}$ (dust deposit corresponding to $3.3 \mathrm{~g} / \mathrm{m}^{2}$ ) deposited on surface of the PV cell. Indeed, they show a significant decrease from $23.62 \mathrm{~mW} / \mathrm{m}^{2}$ to $11 \mathrm{~mW} / \mathrm{m}^{2}$ for dust layer thicknesses ranging from 0 to $70 \mu \mathrm{m}$. Thus, we note a decrease of half of the power produced compared to that of the clean cell. These results confirm those of Majeed et al. [43]. Moreover, these curves show that when the thickness of the layer of dust deposited on the cell increases from 30,45 and $55 \mu \mathrm{m}$ (corresponding respectively to a dust deposit of $1.4,2.1$ and $2.6 \mathrm{~g} / \mathrm{m}^{2}$ ), the power output decreases respectively by 14.12 , 13.66 and $12.816 \mathrm{~mW} / \mathrm{m}^{2}$. 
Figure 6 shows current-voltage characteristics between clean cell (dust layer thickness $0 \mu \mathrm{m}$ ) and room cell (dust layer thickness $70 \mu \mathrm{m}$ ) (black curves) and power-voltage characteristics of the silicon-based photovoltaic cell between clean cell (dust layer thickness $0 \mu \mathrm{m}$ ) and room cell (dust layer thickness $70 \mu \mathrm{m}$ ) (blue curves). Indeed, they show that the maximum power point (PPM) (corresponding to $0.46 \mathrm{~mA} ; 51.36 \mathrm{~mW})$ of the clean cell increases from $(0.44 \mathrm{~mA} ; 25.038$ $\mathrm{mW}$ ) to unclean cell of dust deposit corresponding to $3.3 \mathrm{~g} / \mathrm{m}^{2}$. This decrease in production corresponds to a decrease in maximum power from 23.63 to 11.016 $\mathrm{mW}$ corresponding to a $53 \%$ decrease in production compared to the clean cell. These losses are quite low compared to results of Nimmo and Said [44] who noted $65 \%$ decrease. These differences in value could be due to different compositions of the Kuwaiti dust but also to climatic conditions. For variation of dust layer thickness from 0 to $70 \mu \mathrm{m}$, power loss of about $12.614 \mathrm{~mW}$ observed. Overall, this figure confirms results of Jiang and $\mathrm{Lu} \mathrm{[40]} \mathrm{who} \mathrm{showed} \mathrm{that} \mathrm{depo-}$ sition of dust on PV cell surfaces decreases output power of the cell. According to Ndiaye et al. [6] decrease in cell power is due to the decrease in irradiance. Indeed, the illumination flux is reflected by dust layers.

Figure 7 shows conversion efficiency of silicon cell for different dust layers deposited on cell surface as a function of the size of dust layer. By increasing dust deposit on the cell surface by $(30,45,55$ and $70 \mu \mathrm{m})$ corresponding to 1.4 , 2.1, 2.6 and $3.3 \mathrm{~g} / \mathrm{m}^{2}$ respectively, the conversion efficiency of PV cell increases from $23 \%$ to $11 \%$. When layer of dust $70 \mu \mathrm{m}$ (corresponding to a deposit of 3.3 $\mathrm{g} / \mathrm{m}^{2}$ ) deposited on surface of PV cell, conversion efficiency of the cell increases from $23 \%$ to $11 \%$. Thus, we can see that half of the cells production is lost due to dust. These results corroborate to Chen et al, Guan et al. and Ramli et al. [32] [45] [46] They concluded that productivity efficiency of photovoltaic cells decreases when dust accumulates on their surfaces. These studies have shown that decrease in performance is due to reduced absorption of solar energy, as a small fraction of the solar radiation passes through the dust layer and reaches the surface of the PV module. Furthermore, according to Klugmann-Radziemska and Hegazy [42] [47], the decrease in efficiency is due to decrease in light transmission through the glass cover when dust accumulates on PV cell surfaces. According to Ndiaye et al. Rao et al. [6] [23] the decrease in efficiency could be due to the increase in temperature above the cell caused by the absorption of light by the dust layers.

Figure 8 shows the fill factor of silicon-based cell for different layers of dust deposited on cell surface. Indeed, this parameter provides information on quality of cell. For layer thickness variation from 0 to $70 \mu \mathrm{m}$, fill factor decreases from $76 \%$ to $50 \%$. This decrease corresponds to $26 \%$ compared to clean cell. Thus, this curve confirms degradation caused by dust on surfaces of monocrystalline silicon cells. The reduction of this factor is favored by the increase in temperature on PV cell surface. It is due to absorption of photons and light by dust atoms according to Ahmed et al. [48]. The decrease of the fill factor could be due to the 


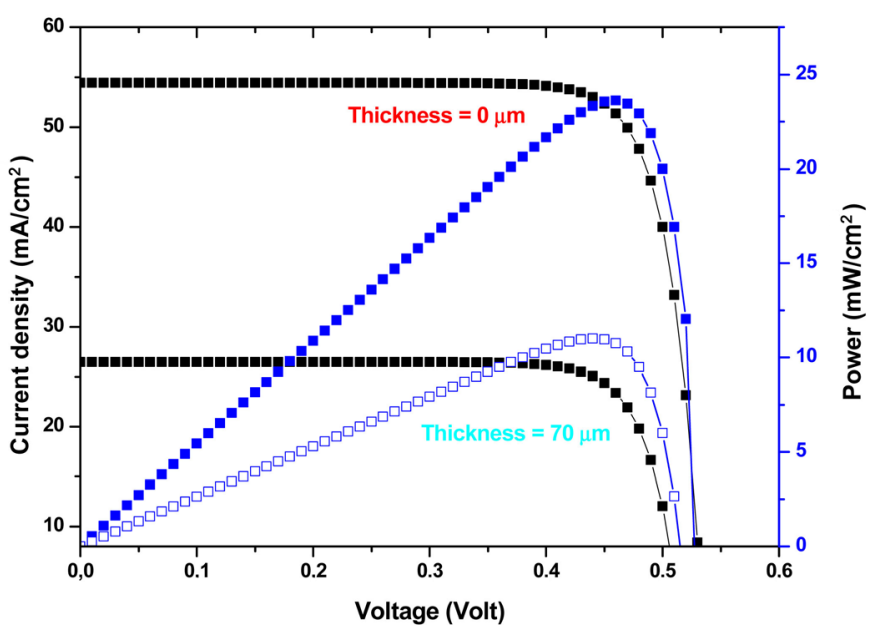

Figure 6. Current-voltage characteristic for clean PV cell (dust layer thickness $0 \mu \mathrm{m}$ ) and room PV cell (dust layer thickness $70 \mu \mathrm{m}$ ) (black curves); Power-voltage characteristic for clean cell (dust layer thickness $0 \mu \mathrm{m}$ ) and room cell (dust layer thickness $70 \mu \mathrm{m}$ ) (blue curves).

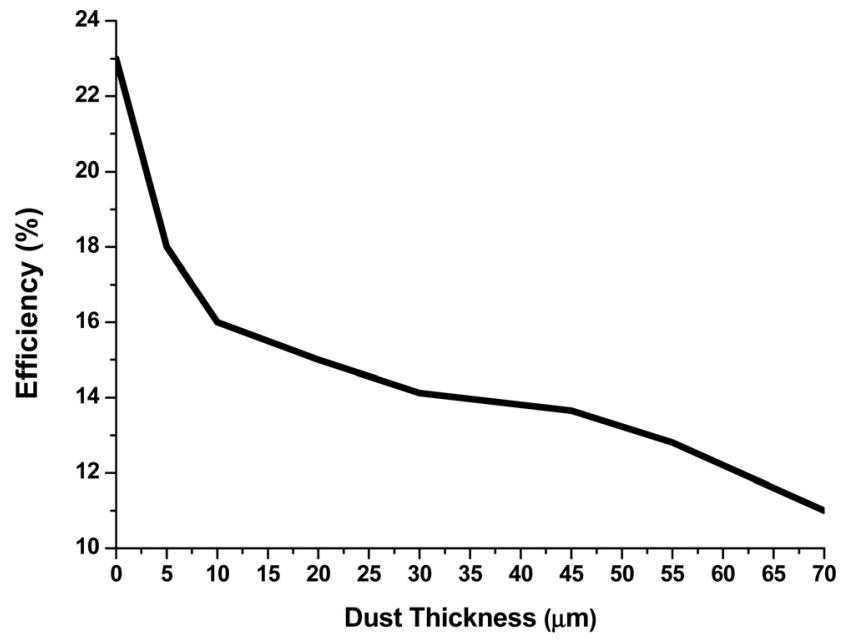

Figure 7. Cell conversion efficiency for different dust layer thicknesses.

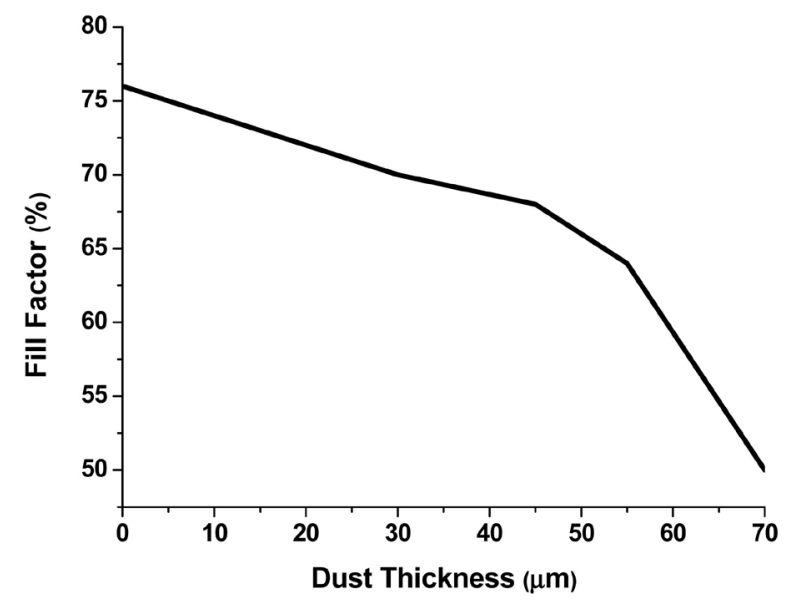

Figure 8. Cell form factor for different dust layer thicknesses. 
increase in series resistance of the PV cell when the dust layer increases. Furthermore, the behavior of the curve could be due to the difference in size of dust particles or the structural properties of the collected dust [49] [50].

\section{Conclusions}

This work evaluated the influence of dust deposition on the electrical performance of silicon-based photovoltaic cells by a model. Thus, the analysis of loss of electrical characteristics as a function of dust is studied. Indeed, it allowed us to evaluate the losses of electrical characteristics such as production efficiency, power output, short-circuit current and fill factor of monocrystalline silicon-based photovoltaic cells as a function of dust deposited on the surface of these solar modules in Dakar, Senegal.

Firstly, this work showed that the deposition of dust on PV cell surfaces does not significantly change open circuit voltage. However, short-circuit current affected by this dust deposit with loss of about $51 \%$ for a dust layer of $70 \mu \mathrm{m}$ (corresponding to dust deposit of $3.3 \mathrm{~g} / \mathrm{m}^{2}$ ) compared to clean cell current. Moreover, the main conclusion is that a cleaning of the cell should be considered in order to optimize its electrical performance from dust layer thickness of $70 \mu \mathrm{m}$ (corresponding to dust deposit of $3.3 \mathrm{~g} / \mathrm{m}^{2}$ ).

However, it would be interesting to extend this work by introducing into this model, the influence of cell temperature but also by comparing it with experimental studies. In addition, the realization of multi-layers of dust and glass on the silicon cell could allow to measure the electrical parameters in real-time. This study also has limitations because type of dust is not specified and dust layers are assumed to be homogeneous. So, it would also make sense to take into account the binding of dust atoms on the surfaces of PV modules.

\section{Conflicts of Interest}

The authors declare no conflict of interest regarding the publication of this paper.

\section{References}

[1] IEA (2014) Technology Roadmap: Solar Photovoltaic Energy. International Energy Agency, Paris.

[2] Al-Waeli, A.H.A., Chaichan, M.T., Sopian, K., Kazem, H.A., Mahood, H.B. and Khadom, A.A. (2019) Modeling and Experimental Validation of a PVT System Using Nanofluid Coolant and Nano-PCM. Solar Energy, 177, 178-191.

https://doi.org/10.1016/j.solener.2018.11.016

[3] Drame, M., Ould Bilal, B., Camara, M., Sambou, V. and Gaye, A. (2012) Impacts of Aerosols on Available Solar Energy at Mbour, Senegal. Journal of Renewable and Sustainable Energy, 4, Article ID: 013105. https://doi.org/10.1063/1.3682078

[4] Diouf, B., Pode, R. and Osei, R. (2013) Initiative for 100\% Rural Electrification in Developing Countries: Case Study of Senegal. Energy Policy, 59, 926-930.

https://doi.org/10.1016/j.enpol.2013.04.012

[5] Youm, I., Sarr, J., Sall, M. and Kane, M.M. (2000) Renewable Energy Activities in 
Senegal: A Review. Renewable and Sustainable Energy Reviews, 4, 75-89. https://doi.org/10.1016/S1364-0321(99)00009-X

[6] Ndiaye, A., Kébé, C.M., Ndiaye, P.A., Charki, A., Kobi, A. and Sambou, V. (2013) Impact of Dust on the Photovoltaic (PV) Modules Characteristics after an Exposition Year in Sahelian Environment: The Case of Senegal. International Journal of Physical Sciences, 8, 1166-1173.

[7] Dajuma, A., Yahaya, S., Touré, S., Diedhiou, A., Adamou, R., Konaré, A. and Golba, M. (2016) Sensitivity of Solar Photovoltaic Panel Efficiency to Weather and Dust over West Africa: Comparative Experimental Study between Niamey (Niger) and Abidjan (Côte d'Ivoire). Computational Water, Energy, and Environmental Engineering, 5, 123-147. https://doi.org/10.4236/cweee.2016.54012

[8] Youm, I., Sarr, J., Sall, M., Ndiaye, A. and Kane, M.M. (2005) Analysis of Wind Data and Wind Energy Potential along the Northern Coast of Senegal. Revue des Energies Renouvelables, 8, 95-108. http://www.webreview.dz/spip.php?rubrique191

[9] Mani, M. and Pillai, R. (2010) Impact of Dust on Solar Photovoltaic (PV) Performance: Research Status, Challenges and Recommendations. Renewable and Sustainable Energy Reviews, 14, 3124-3131. https://doi.org/10.1016/j.rser.2010.07.065

[10] Heimsath, A. and Nitz, P. (2019) The Effect of Soiling on the Reflectance of Solar Reflector Materials-Model for Prediction of Incidence Angle Dependent Reflectance and Attenuation Due to Dust Deposition. Solar Energy Materials and Solar Cells, 195, 258-268. https://doi.org/10.1016/j.solmat.2019.03.015

[11] Tanesab, J., Parlevliet, D., Whale, J. and Urmee, T. (2019) The Effect of Dust with Different Morphologies on the Performance Degradation of Photovoltaic Modules. Sustainable Energy Technologies and Assessments, 31, 347-354. https://doi.org/10.1016/j.seta.2018.12.024

[12] Gupta, V., Sharma, M., Pachauri, R.K. and Babu, K.D. (2019) Comprehensive Review on Effect of Dust on Solar Photovoltaic System and Mitigation Techniques. Solar Energy, 191, 596-622. https://doi.org/10.1016/j.solener.2019.08.079

[13] Alnasser, T.M., Mahdy, A.M., Abass, K.I., Chaichan, M.T. and Kazem, H.A. (2020) Impact of Dust Ingredient on Photovoltaic Performance: An Experimental Study. Solar Energy, 195, 651-659. https://doi.org/10.1016/j.solener.2019.12.008

[14] Marticorena, B., Bergametti, G., Aumont, B., Callot, Y., N’Doumé, C. and Legrand, M. (1997) Modeling the Atmospheric Dust Cycle: 2. Simulation of Saharan Dust Sources. Journal of Geophysical Research: Atmospheres, 102, 4387-4404. https://doi.org/10.1029/96JD02964

[15] Paudyal, B.R. and Shakya, S.R. (2016) Dust Accumulation Effects on Efficiency of Solar PV Modules for Off Grid Purpose: A Case Study of Kathmandu. Solar Energy, 135, 103-110. https://doi.org/10.1016/j.solener.2016.05.046

[16] Kaldellis, J.K. and Kapsali, M. (2011) Simulating the Dust Effect on the Energy Performance of Photovoltaic Generators Based on Experimental Measurements. Energy, 36, 5154-5161. https://doi.org/10.1016/j.energy.2011.06.018

[17] Moehlecke, A., Febras, F.S. and Zanesco, I. (2013) Electrical Performance Analysis of PV Modules with Bifacial Silicon Solar Cells and White Diffuse Reflector. Solar Energy, 96, 253-262. https://doi.org/10.1016/j.solener.2013.07.028

[18] Chanchangi, Y.N., Ghosh, A., Sundaram, S. and Mallick, T.K. (2020) An Analytical Indoor Experimental Study on the Effect of Soiling on PV, Focusing on Dust Properties and PV Surface Material. Solar Energy, 203, 46-68. https://doi.org/10.1016/j.solener.2020.03.089

[19] Adıgüzel, E., Özer, E., Akgündoğdu, A. and Yllmaz, A.E. (2019) Prediction of Dust 
particle Size Effect on Efficiency of Photovoltaic Modules with ANFIS: An Experimental Study in Aegean Region, Turkey. Solar Energy, 177, 690-702.

https://doi.org/10.1016/j.solener.2018.12.012

[20] Hachicha, A.A., Al-Sawafta, I. and Said, Z. (2019) Impact of Dust on the Performance of Solar Photovoltaic (PV) Systems under United Arab Emirates Weather Conditions. Renewable Energy, 141, 287-297.

https://doi.org/10.1016/j.renene.2019.04.004

[21] Jiang, H., Lu, L. and Sun, K. (2011) Experimental Investigation of the Impact of Airborne Dust Deposition on the Performance of Solar Photovoltaic (PV) Modules. Atmospheric Environment, 45, 4299-4304.

https://doi.org/10.1016/j.atmosenv.2011.04.084

[22] Said, S.A. and Walwil, H.M. (2014) Fundamental Studies on Dust Fouling Effects on PV Module Performance. Solar Energy, 107, 328-337. https://doi.org/10.1016/j.solener.2014.05.048

[23] Rao, A., Pillai, R., Mani, M. and Ramamurthy, P. (2014) Influence of Dust Deposition on Photovoltaic Panel Performance. Energy Procedia, 54, 690-700.

https://doi.org/10.1016/j.egypro.2014.07.310

[24] Faye, D., Gueye, S., Ndiaye, M., Ba, M.L., Diatta, I., Traore, Y. and Sissoko, G. (2020) Lamella Silicon Solar Cell under Both Temperature and Magnetic Field: Width Optimum Determination. Journal of Electromagnetic Analysis and Applications, 12, 43-55. https://doi.org/10.4236/jemaa.2020.124005

[25] Diao, A., Wade, M., Thiame, M. and Sissoko, G. (2017) Bifacial Silicon Solar Cell Steady Photoconductivity under Constant Magnetic Field and Junction Recombination Velocity Effects. Journal of Modern Physics, 8, 2200-2208. https://doi.org/10.4236/jmp.2017.814135

[26] Mahfoud, A. (2018) Modélisation des cellules solaires tandem à couches minces et à haut rendement (Doctoral Dissertation).

[27] Ghandhi, S.K. (1977) Semiconductor Power Devices: Physics of Operation and Fabrication Technology. Wiley, New York, 329. http://dspace.univ-setif.dz:8888/jspui/handle/123456789/1785

[28] Adolf, G., Joachim, K. and Bernhard, V. (1998) Crystalline Silicon Solar Cells. Fraunhofer Institute for Solar Energy Systems, Freiburg.

[29] Orieux, A., Versteegh, M.A., Jöns, K.D. and Ducci, S. (2017) Semiconductor Devices for Entangled Photon Pair Generation: A Review. Reports on Progress in Physics, 80, Article ID: 076001. https://doi.org/10.1088/1361-6633/aa6955

[30] Jain, V.K. and Verma, A. (2013) Physics of Semiconductor Devices: 17th International Workshop on the Physics of Semiconductor Devices. Springer Science \& Business Media, Berlin. https://doi.org/10.1007/978-3-319-03002-9

[31] Thompson, G.H.B. (1980) Physics of Semiconductor Laser Devices.

[32] Chen, Y., Wang, D., Liu, Y., Dong, Y. and Liu, J. (2019) Research on Photovoltaic Performance Reduction Due to Dust Deposition: Modelling and Experimental Approach. Journal of Thermal Science, 28, 1186-1194. https://doi.org/10.1007/s11630-019-1177-6

[33] Colinge, J.P. and Colinge, C.A. (2005) Physics of Semiconductor Devices. Springer Science \& Business Media, Berlin.

[34] Colarco, P.R., Toon, O.B., Torres, O. and Rasch, P.J. (2002) Determining the UV Imaginary Index of Refraction of Saharan Dust Particles from Total Ozone Mapping Spectrometer Data Using a Three-Dimensional Model of Dust Transport. Journal of Geophysical Research: Atmospheres, 107, AAC 4-1-AAC 4-18. 
https://doi.org/10.1029/2001JD000903

https://agupubs.onlinelibrary.wiley.com/action/doSearch?ContribAuthorStored=Ra sch\%2C+Philip+J

[35] Sokolik, I.N. and Toon, O.B. (1999) Incorporation of Mineralogical Composition into Models of the Radiative Properties of Mineral Aerosol from UV to IR Wavelengths. Journal of Geophysical Research: Atmospheres, 104, 9423-9444. https://doi.org/10.1029/1998JD200048

[36] Péré, J.C., Rivellini, L., Crumeyrolle, S., Chiapello, I., Minvielle, F., Thieuleux, F. and Popovici, I. (2018) Simulation of African Dust Properties and Radiative Effects during the 2015 SHADOW Campaign in Senegal. Atmospheric Research, 199, 14-28. https://doi.org/10.1016/j.atmosres.2017.07.027

[37] Fouquart, Y., Bonnel, B., Brogniez, G., Buriez, J.C., Smith, L., Morcrette, J.J. and Cerf, A. (1987) Observations of Saharan Aerosols: Results of ECLATS Field Experiment. Part II: Broadband Radiative Characteristics of the Aerosols and Vertical Radiative Flux Divergence. Journal of Climate and Applied Meteorology, 26, 38-52. https://doi.org/10.1175/1520-0450(1987)026<0038:OOSARO>2.0.CO;2

[38] Kaufman, Y.J., Karnieli, A. and Tanré, D. (2000) Detection of Dust over Deserts Using Satellite Data in the Solar Wavelengths. IEEE Transactions on Geoscience and Remote Sensing, 38, 525-531. https://doi.org/10.1109/36.823947

[39] Veselovskii, I., Goloub, P., Podvin, T., Bovchaliuk, V., Derimian, Y., Augustin, P. and Diallo, A. (2016) Retrieval of Optical and Physical Properties of African Dust from Multiwavelength Raman Lidar Measurements during the SHADOW Campaign in Senegal. Atmospheric Chemistry and Physics, 16, 7013. https://doi.org/10.5194/acp-16-7013-2016

[40] Jiang, Y. and Lu, L. (2016) Experimentally Investigating the Effect of Temperature Differences in the Particle Deposition Process on Solar Photovoltaic (PV) Modules. Sustainability, 8, 1091. https://doi.org/10.3390/su8111091

[41] Abdolzadeh, M. and Nikkhah, R. (2019) Experimental Study of Dust Deposition Settled over Tilted PV Modules Fixed in Different Directions in the Southeast of Iran. Environmental Science and Pollution Research, 26, 31478-31490. https://doi.org/10.1007/s11356-019-06246-z

[42] Klugmann-Radziemska, E. (2015) Degradation of Electrical Performance of a Crystalline Photovoltaic Module Due to Dust Deposition in Northern Poland. Renewable Energy, 78, 418-426. https://doi.org/10.1016/j.renene.2015.01.018

[43] Majeed, R., Waqas, A., Sami, H., Ali, M. and Shahzad, N. (2020) Experimental Investigation of Soiling Losses and a Novel Cost-Effective Cleaning System for PV Modules. Solar Energy, 201, 298-306. https://doi.org/10.1016/j.solener.2020.03.014

[44] Nimmo, B.R. and Said, S.A. (1981) Effects of Dust on the Performance of Thermal and Photovoltaic Flat Plate Collectors in Saudi Arabia: Preliminary Results. Alternative Energy Sources II, 1, 145-152.

https://ui.adsabs.harvard.edu/abs/1981aes.....1..145N/abstract

[45] Guan, Y., Zhang, H., Xiao, B., Zhou, Z. and Yan, X. (2017) In-Situ Investigation of the Effect of Dust Deposition on the Performance of Polycrystalline Silicon Photovoltaic Modules. Renewable Energy, 101, 1273-1284.

https://doi.org/10.1016/j.renene.2016.10.009

[46] Ramli, M.A., Prasetyono, E., Wicaksana, R.W., Windarko, N.A., Sedraoui, K. and Al-Turki, Y.A. (2016) On the Investigation of Photovoltaic Output Power Reduction Due to Dust Accumulation and Weather Conditions. Renewable Energy, 99, 836-844. https://doi.org/10.1016/j.renene.2016.07.063 
[47] Hegazy, A.A. (2001) Effect of Dust Accumulation on Solar Transmittance through Glass Covers of Plate-Type Collectors. Renewable Energy, 22, 525-540. https://doi.org/10.1016/S0960-1481(00)00093-8

[48] Ahmed, Z., Kazem, H.A. and Sopian, K. (2013) Effect of Dust on Photovoltaic Performance: Review and Research Status. Latest Trends in Renewable Energy and Environmental Informatics, 34, 193-199.

[49] Boccard, M. and Ballif, C. (2020) Influence of the Subcell Properties on the Fill Factor of Two-Terminal Perovskite-Silicon Tandem Solar Cells. ACS Energy Letters, 5, 1077-1082. https://doi.org/10.1021/acsenergylett.0c00156

[50] Martini, L., Serenelli, L., Menchini, F., Izzi, M. and Tucci, M. (2020) Silicon Heterojunction Solar Cells toward Higher Fill Factor. Progress in Photovoltaics: Research and Applications, 28, 307-320. https://doi.org/10.1002/pip.3241 